\title{
Regional Social-environmental Ethics as an approach to Regional Development
}

\author{
Luciano Félix Florit \\ Carlos Alberto Cioce Sampaio
}

${ }^{I}$ Graduation Program in Regional Development, Regional University in Blumenau, Blumenau, Santa Catarina, Brazil.

II Graduation Program in Regional Development, Regional University in Blumenau, Blumenau, Santa Catarina, Brazil. Manfred Max- Neef Fundation, Valdivia, Los Lagos Región, Chile.

\begin{abstract}
The development concepts fail to correlate the social issues and overall, the ecological issues with a long-term country project. The ethical political reflection around development patterns is therefore a decisive reflection. The aim is to dialogue about regional development from the standpoint of categories of socio-environmental ethics. It is exploratory research which is supported empirically in documental analysis of two cases of the regionalization process of the state of Santa Catarina (Brazil). It concludes that recognizing legitimate moral limits to the use of landscapes and living beings would be an important step in development planning, which requires a territorial reading. This is ignored by exclusively technical discourses and ecological common sense.
\end{abstract}

Keywords: Regional development; Socio environmental ethics; Human and non-human living beings; Santa Catarina; Territory.

São Paulo. Vol. 24, 2021

Original Article

DOI: http://dx.doi.org/10.1590/1809-4422asoc20200122r2vu2021L5AO 


\section{Introduction}

Thinking about development is to be confronted with conceptions of society that assume that they have ways of meeting collective needs and achieving a supposedly desirable future. For this reason, much of the disputes and controversies surrounding development are disputes over ideas of how society should be.

However, most of the time, this normative confrontation remains implicit, either because the theoretical perspectives used do not make their references explicit, or because common sense passively adheres to naturalized or hegemonic normative impositions. On the other hand, disputes between ideas and conceptions are not resolved only in the field of arguments, but in a dialectic of argumentative positions and positions of power.

Therefore, in a country like Brazil, so unequal in economic, symbolically, territorially, and in terms of biodiversity and sociodiversity symbolic, the clarification of the normative variable is essential. Currently, the economic agenda disproportionately supported by primary resources and the immense political weight of common sense reproduced in large urban conglomerates, give rise to conceptions of development that cannot consistently correlate the ecological issue with a long-term country project.

This difficulty is historic in Brazil, but it has been accentuated in recent decades. Although with different nuances, it was present in periods of developmental policies and is observed now, when the most purely neoliberal agendas have imposed themselves as if there were no alternatives to them. Normative reflection around development patterns is therefore a crucial reflection.

Among the normative aspects of development, there are two premises that political ethical reflection affects environmental issues and that it establishes as unequivocally relevant: (i) the elimination of environmental inequalities among human groups and; (ii) the effective recognition that non-human living beings have intrinsic value, therefore, they should not be objectified. Indeed, even if the realization of these premises is complex and the subject of much controversy, it is unlikely to find among reputable thinkers who deal with environmental issues someone who denies that the disproportion with which the environmental burdens and bonuses are distributed between powerful and vulnerable groups is an affront to fundamental criteria of socio-environmental justice. Likewise, even though it is one of the thorniest problems of our time, given the complex intersection it has with various aspects of social life, it is difficult to find among these thinkers someone who does not admit that there is an evident problem in the radical instrumentalization that is done. of non-human living beings and also of other natural beings, such as rivers, mountains, and landscapes.

Faced with this issue, the objective is to dialogue about regional development from categories of normative socio-environmental ethics. Our purpose is to apply these categories to two processes of regionalization in $\mathrm{SC}$, where the look of socio-environmental ethics reveals naturalized inequities affecting humans, animals, and landscapes. One of the cases concerns the pattern of regional development linked to industrial livestock, which combines a radical objectification of non-human beings with the vulnerability of the humans who work in it, in addition to the environmental consequences per se, such 
as the water stress that the model generates. The other case deals with the sociocultural imposition of the colonial interpretation of the landscape in the Vale do Itajaí (the "European Valley"), which functions as a legitimizing basis for the segregation of other landscape valuations not assimilated to the urban-industrial-capitalist project. This look highlights the significance of one of the main territorial environmental conflicts in SC, which is the North Dam that has affected the Laklano-Xokleng people for almost fifty years.

Methodologically, this is exploratory research that uses official documents from the State of Santa Catarina (Brazil), as well as academic works that deal with the two illustrated cases.

\section{Regional Development from the perspective of socio-environmental}

\section{Ethics}

As mentioned, disputes over regional development, in addition to involving conflicts of interest, also express disputes over the vision of what development processes should be. Such disputes imply value assumptions that define the substantive purposes of development, also including questions about the kind of acceptable relationship between human beings and nature, landscapes, and non-human living beings.

The "territorial" perspective is one way of approaching these controversies. The territory is a space that, despite having its physical base, is identified by the social web that characterizes it, both by the socio-economic, socio-political, and socio-ecological dimensions, as well as by the environmental values that are mobilized in it.

In the literature on the subject, the concept of territory has two main meanings (ANTONSICH, 2011). The first, from Anglo-Saxon geography, privilege the understanding of the territory as a political and institutional phenomenon, in which the figure of the sovereign State plays a leading role (MÜLLER, 2011; SILVA; FERREIRA-LOPES, 2014; BREKKE, 2015). The second, from Francophone geography, establishes the understanding of the territory as a social phenomenon, with cultural roots, in the sense that territories are produced by the people who build them (FRIEDMAN; DESIVILYA, 2010; GENNAIOLI et al., 2013; DANA et al., 2013; DANA et al., 2013; al., 2014).

Both perspectives recognize that human territoriality manifests itself in power operations that define what can or cannot be done in the territory or what is acceptable or inadmissible on one side or the other of a border (SACK, 2011). This happens through instruments of control or value judgments, both inseparable from the positions of power of the actors involved.

Territorialization processes are a fundamental aspect of the consolidation of lasting economic and political orders, which are generally consecrated and reproduced by the State or with the articulation among the latter and the power groups established in the territory. This articulation results in the regionalization of development patterns, constituted by economic and institutional arrangements (THEIS, 2008).

From an environmental point of view, these territorialization processes imply the transformation of the landscape and the appropriation of resources, both supported 
by socially defined visions of nature (FLORIT, 2004). The result is that economic and political-cultural patterns are associated with a "region" that indicates the concrete geographic space where they operate and from which they obtain the means of reproduction (THEIS, 2008).

On the other hand, thanks to the heritage of cultural anthropology, it is known that, when re-discussing the relationship between nature and non-human living beings, moral values and judgments are inevitably imputed. This takes on a new configuration in the contemporary context, whether it is characterized as a society of risk, manufactured uncertainty, climate change, or Anthropocene (BECK, 1992; GIDDENS, 1993; DANOWSKI; VIVEIROS DE CASTRO, 2014; DOUGLAS, 1966) without being have a due reflection on a public scale of the moral dilemmas they raise. What we currently have is that the properly ethical discussion regarding nature has been ignored and hidden behind the monetary metric of assigning value to things, privileging what is priceable as a criterion to define what should be considered relevant concerning nature.

This timid discussion related to valuation contains elements strongly linked to the territory. Although we are talking about an issue that has a civilizational character, it appears with defined and geographically identifiable characteristics. For example, while the world is discussing the recognition of the sentience of animals, in Santa Catarina the increase and concentration of the production of poultry and pigs are being planned as if this issue did not exist. Or, at the same time that sustainability is discussed, it is a matter of contempt for ways of life that use nature sparingly and with ecological intelligence, like native peoples and other traditional communities.

It is here that the interface between ethics and regional development is established. Ethics is the systematic reflection that philosophers or reflective subjects make about the foundations and principles of morality or moralities (PEDRO, 2014). It is a theoretical and speculative investigation, although not necessarily academic, capable of assisting in the critical analysis of the moral conditions mobilized in different socio-environmental contexts. Although intertwined with sociological and territorial reflection, it differs from this insofar as its analysis turns to the normative contents themselves, while in the sociological dimension the analysis turns to the reproduction or change of the moralities of different social groups.

When dealing with ethics or philosophy of morals in the sense of a systematic reflection on the validity of moral judgments, it refers to a phenomenon that is different from the existence of moralities in the sociological sense of the term (RACHEL; RACHELS, 2013). While the former is fundamentally supported by arguments, the latter consist of the application of moral valuations and judgments resulting from naturalized cognitions constituted in contexts of social reproduction, often linked to power relations. In both cases, there are moral evaluations and judgments. The basic difference consists in the fact that in the first one what predominates are rational arguments and in the second what predominates are naturalized cognitions and power relations.

This is due to the existence of two distinct but interrelated domains and phenomena. One of a reflexive and speculative character and the other resulting from social relations. 
Socially dominant moralities, despite their inconsistencies and unsustainable aspects based on rational argument, tend to continue and reproduce. This tendency does not necessarily result from the ethical validity of its foundations, but from the social relations of power in which they were generated and to which they continue to be linked (BERGER, 2000).

On the other hand, it appears that these power relations are rarely changed based only on arguments. Indeed, while arguments may be an important element of disputes, they are certainly not limited to them. In them, economic, political, and territorial relations play a fundamental role.

This distinction between ethics and moralities is important because it allows us to understand how, although ethical reasoning often converges with the dominant morality, there are occasions when the opposite occurs, that is, ethical reasoning leads to the questioning of socially established moralities. This is exactly what happens in the context of environmental ethics about anthropocentrism, which is naturalized in the dominant morality. This anthropocentrism, defined and protected by Western classical philosophical moral traditions, underlies the political, economic, and developmental conceptions that justified the impulse to transform nature for human use and domain, and is the basis of the very notion of development and the standards arising from it.

Rooted in the anthropocentric view, the logic of individualism emerges, which deforms individuality. In turn, individuality gives substance and uniqueness to the individual, which constitutes an element that creates a meaning of identity with the community. Otherwise, in the absence of individuality, all communities would run the risk of being equal (BAUMAN, 2003). Anthropocentrism continues to be exacerbated in the dominant morality of globalized capitalism, as it tends to recognize in nature only an instrumental value, with monetization as the dominant metric of value.

Whether, on the one hand, there is a need for ethical reflection itself, on the other hand, it is also necessary to pay attention to the aspects that relate ethics to power and territory. Therefore, it is important to distinguish two sets of phenomena that, although interdependent, are distinct: (i) ethical reflection on environmental values and; (ii) that of the social reproduction of moral values in concrete societies or territories. Although these are aspects that interrelate in social life (PEDRO, 2014), to understand the challenge involved in explaining environmental normative assumptions when dealing with development, it is important to realize that they originally refer to different domains.

Environmental ethics is the field of critical reflection on the values through which relationships with nature and non-human living beings are established (ELLIOT, 2004). This definition includes wild landscapes and the elements that compose them, but it also includes beings that are the result of anthropic manipulation. Animal ethics should be seen as a branch of environmental ethics, including here the issue of the treatment of wild and domesticated animals (KUHNEN, 2016). Social and environmental ethics would be the field of reflection that makes an interface between environmental ethics and social studies of environmental inequities (MARZOCHI; FLORIT, 2018; FLORIT, 2017). On the analytical level, socio-environmental ethics implies studying the social relations that result in the moral disregard for nature and non-human living beings, which, in the 
contemporary context, is called objectification or objectification. On a normative level, it implies reconciling the moral consideration of these living beings with the affirmation of environmental justice among human beings, in concrete territories, in intraregional and interregional relationships that often observe inter-scalar links that are determinant (SANTOS; PIROLI, 2020).

When it comes to environmental justice, it refers to the perspective that has been emphasizing the analysis of inequities that permeate environmental conflicts. These fundamentally result from structural inequalities of an unequal society and lead to a disproportionate distribution of environmental burdens to the most vulnerable social groups, as well as implying favoring access to environmental goods and services for the most powerful groups (ACSELRAD, 2008).

In this sense, it is essential to note that environmental inequalities often involve more deeply traditional peoples and communities, whose way of life is closely related to valuations of nature that are very different from the hegemonic standards in the context of global capitalism. Thus, in the construction of socio-environmental ethics, it is necessary to pay special attention to conflicts that affect populations that maintain peculiar conceptions of nature, such as indigenous peoples, quilombolas, farmers partially integrated into the market or focused on agroecology and various categories of traditional communities, for whom the use of nature is not limited to objectification and monetized valuation (FLORIT, 2016; 2017).

From the intersection of these approaches results from the perspective of socioenvironmental ethics that is constituted as illustrated in Table 1.

Table 1: Environmental perspectives to social equity and Anthropocentrism

\begin{tabular}{|l|l|l|}
\hline & No equity & Equity \\
\hline Anthropocentric & Ecological common sense & Environmental Justice \\
\hline Not anthropocentric & Environmental Ethics & $\begin{array}{l}\text { Social and Environmental } \\
\text { Ethics }\end{array}$ \\
\hline
\end{tabular}

Source: Florit, Sampaio e Philippi Jr. (2019)

This matrix, which crosses two major variables, results in a typology of four perspectives that make it possible to generically distinguish the characteristics of socioenvironmental ethics.

In the columns, the environmental equity variable distinguishes ecological common sense from environmental justice. The expression common sense is borrowed, in the sense that Acselrad (2008) uses, to distinguish the hegemonic perspective from the perspective of environmental justice, which he develops. The first considers the most hegemonic perspectives such as ecological modernization and the green economy, which tend to deal with environmental problems only in their technical aspects and to value in nature only what the market recognizes in monetary terms. The second covers the 
perspectives that give centrality to the disproportionate distribution of environmental burdens and bonuses, resulting from inequalities inherent in the processes of appropriation of nature, construction of territory, and socio-spatial segregation. This perspective allows us to see that there are social groups whose relationship with nature and territoriality is marked by economic and socio-cultural logics that are distinct from those typically urban-industrial-capitalist.

Along these lines, the variable of anthropocentrism highlights the perspectives that assume the implications of critical reflection on the instrumental reduction of nature and non-human beings. In this aspect, ecological common sense is in line with anthropocentrism, while environmental ethics (which also includes animal ethics) highlights the perspectives that criticize the merely instrumental treatment, characteristic of hegemonic perspectives.

It is observed, however, that if, on the one hand, the hegemonic perspectives of ecological common sense are imbued with the two flaws (lack of equity and naturalized anthropocentrism), criticisms of environmental justice and environmental ethics are, although very relevant, also partial or incomplete. In general, accepting the risk of some unfair generalization, it is possible to say that the analyzes of environmental justice tend to fall back on anthropocentric epistemological bases, typical of the theoretical matrices of modernity. There are, it must be said, analyzes that take perspectives that distance themselves from the modern matrix of thought, such as decolonial ones. However, even in these perspectives, the centrality of the man/nature dualism on which the moral value/ instrumental value dualism is based, remaining in uncritical anthropocentric positions, is not always recognized.

In turn, albeit with the same caution, it can be said that environmental ethics tends to maintain normative analyzes with non-human beings without necessarily considering the analysis of social relations that imply inequities. Therefore, this aspect of reflection requires making use not only of environmental ethical theories formulated by philosophers, but also other contributions such as the anthropology of nature (which pays attention to the ontological construction of classifications such as "humanity", "animality", "rio", etc.) and the sociology of post-development that perceives in these fields the struggles between ontologically different worlds (ESCOBAR, 2006; DE LA CADENA, 2010; INGOLD, 2012; VIVEIROS DE CASTRO, 2013).

This is how the field of socio-environmental ethics emerges, as the theoreticalepistemological space that tensions the conjunction of the two critical variables, seeking to build approaches that synergistically incorporate criticism of the objectification of nature and criticism of the generation of socio-environmental inequalities.

\section{A look at "regional vocations" in Santa Catarina}

Regionalization operations are a key moment in development processes. Although this is a classic topic of geographic thought, to deal with it in this context of the discussion, it is important to emphasize its aspect of cognitive configuration, that is, the aspect 
that leads to a certain territory being seen by social and state agents as a holder of certain defined characteristics. This means treating them as a specific form of exercising symbolic power, which is the acts of appointment (BOURDIEU, 1989), carried out by state planning agents and by hegemonic social groups.

These procedures are based on selected geographic references, highlighting certain elements over others. Depending on the purposes, explicit or implicit, it is not uncommon for tensions and conflicts that define the configuration of the landscape to be overlooked, and which are, so to speak, inscribed in the territory, even when it is seen as a "natural" landscape" (SOPER, 1966). These operations of reification of regions are complemented by the attribution of specific functions and characteristics, which, in turn, are appropriated and/or incorporated by agents with the power to make the territory through their practices.

These regionalizations, carried out by the State (or by private agents whose vision is incorporated by the State), constitute a peculiar way of exercising symbolic power, pointing out borders that separate geographic spaces from points of view that are functional to agents with specific positions in space Social. They are all the more effective, the more convincing the selection of material and cultural geographic references that give them empirical support, and the greater the recruitment of interests and identities that are included in this definition.

One of the most striking consequences of these regionalization processes occurs when social agents incorporate in their actions and strategies a conception of the territory associated with certain vocations. The so-called "regional vocations" are a discursive strategy supported by the existence of supposed intrinsic trends in certain regions, such as an unquestionable potential for one or another activity, determined by geomorphological and/or cultural characteristics of a territory. These are reifications in which a representation of the region is accepted and incorporated by social agents' co-builders of the landscape and by economic, political, and other agents with the symbolic power to spread their representation of reality. Thus, this representation comes to be seen as a given, concrete, natural and ahistorical reality, that is, as having an identity in itself.

In short, the idea of vocation as a natural propensity, or as a divine design, for an activity hides the fact that it is, in fact, a social and political construction that has social, economic, environmental, and ethical consequences that affect humans and non-humans in a given territory. Thus, in these regions, historically constructed conceptions of nature (FLORIT, 2004; GUDYNAS, 2003) are naturalized and reified as "regional vocations" (FLORIT et al., 2014; GRAVA, 2019).

Figure 1 is the best-known representation of the supposed regional vocations of Santa Catarina. Defined by the territoriality of certain industries or "development poles", this representation implicitly or explicitly determines most of the state's economic planning, since it is an expression of the territorial conception of the main economic agents and the public sector.

It shows how the Western Region is associated with raising pigs and birds. Based on this supposed vocation, specific inter-regional relationships are established, both nationally and internationally, providing other places with products of animal origin. This pattern 
of development rests on the ideologically reproduced premise of equating sentient beings with mere things, as productive specialization requires that animals be considered as raw materials for an industrial process.

This conjunction turns into a robust economic and political system insofar as it relies on "regional vocations", supposedly natural and self-evident, which tend to disregard other productive possibilities. These supposed vocations find support in social and political relations, linked to specific actors, beneficiaries of the conception of nature they express. Among these actors, there are economic groups (large slaughterhouses) and political groups, which participate in state and municipal administrations and carry out political articulations with the federal and global spheres.

The conformation of this region highlights the enormous role played by slaughterhouses and the agro-industrial meat chain in the territory's production. Insofar as this construction is supported by the premise of the radical instrumentalization of non-human sentient beings, mediated by unequal relations between humans, it is possible to say that it is a speciesist regionalization. Insofar as it is marked by a rationalization process integrated with extra-regional markets based on a logic of always increasing the productive scale, it is possible to say that it is intensive speciesism. 


\section{Figure 1: Regional SC Vocations}

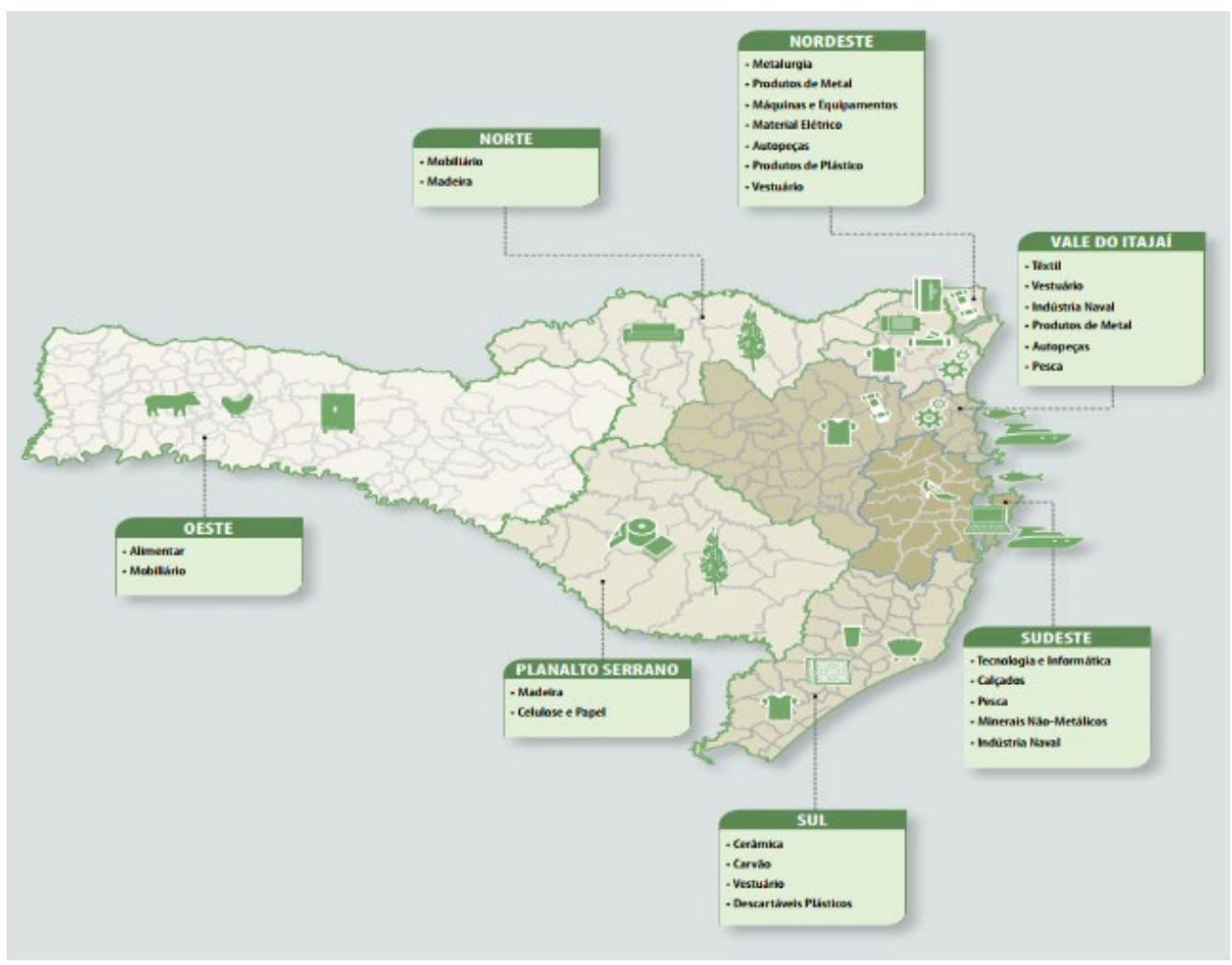

Source: FIESC (2015, p. 14).

Regions of intensive speciesism (REIs) is the concept used in other works to label and give analytical centrality to the issue of speciesism as a dimension of the social dynamics at play in this type of region (FLORIT; GRAVA, 2016; FLORIT; SBERDELATI, 2016; FLORIT et al., 2019).

The per capita slaughter rate indicates the density of non-human sentient beings killed in a specific territory concerning the size of the human population in that same territory. This index differs from calculations that express the total weight of the carcasses or their monetary value, which do not reveal the number of being slaughtered. See table 1 , for example, for this index in the microregion of Concordia. 
Table 1: Per capita slaughter of poultry, cattle and swine, Brazil, Santa Catarina, and the microregion of Concordia-SC, in 2016

\begin{tabular}{|l|r|r|r|}
\hline & População (*) & \multicolumn{1}{|c|}{ Abates (**) } & \multicolumn{1}{c|}{$\begin{array}{c}\text { Abate per } \\
\text { capita }\end{array}$} \\
\hline Brasil & 206.081 .432 & 5.932 .338 .421 & $\mathbf{2 8 , 4 3}$ \\
\hline Santa Catarina & 6.910 .553 & 881.819 .015 & $\mathbf{1 2 7 , 6 0}$ \\
\hline $\begin{array}{l}\text { Microrregião de } \\
\text { Concordia }\end{array}$ & 146.847 & $111.601 .639^{* * *}$ & 759,98 \\
\hline
\end{tabular}

Source: Authors, 2021

Note: Data from *IBGE, 2016, **IBGE, 2017, and *** Ministry of Agriculture, Livestock, and Supply (MAPA), 2016. Includes all cattle, swine, and poultry.

The social and environmental implications of this pattern of development are not limited to the aspects mentioned. It is known that cattle ranching plays a relevant role in climate change and loss of biodiversity, that pig farming is responsible for water pollution and that both have a strong influence on the high "water footprint". There is also an ethical-political reflection focused on dietary patterns that relate the high consumption of meat with consumer health problems, and in this aspect, poultry farming also plays an important role.

But one cannot fail to mention the relationship that exists in the treatment given to animals in systems governed by the "zootechnical ideology" (PORCHER, 2012) and the emergence of viral pathogens among humans. Indeed, as stated by Sordi and Florit (2020), the contemporary way of exploring nature has significantly increased the chance of zoonotic spillovers among wild, domesticated, and human animals. This means that, in a systemic view, the conditions for pandemic events in the globalized world are provided by the accentuated degradation of the natural environment, with pressure on the habitat of wild species; and by the intensification of animal husbandry, with large concentrations in increasingly smaller spaces, and increasingly resistant pathogens due to continued exposure to antibiotics (SORDI; FLORIT, 2020). Therefore, when sociotechnical systems are shielded from moral objections to radical productive objectification, as occurs in Species-Intensive Regions, the favorable conditions for the appearance of new pathogens are even more favored.

Figure 3 shows another representation of regions that are very influential in defining identities, high-impact performative discourses, and also economic activities. It is the tourist regionalization of the state of SC that, among others, defines the "European Valley". 
Figure 2: Tourist Regionalization of Santa Catarina

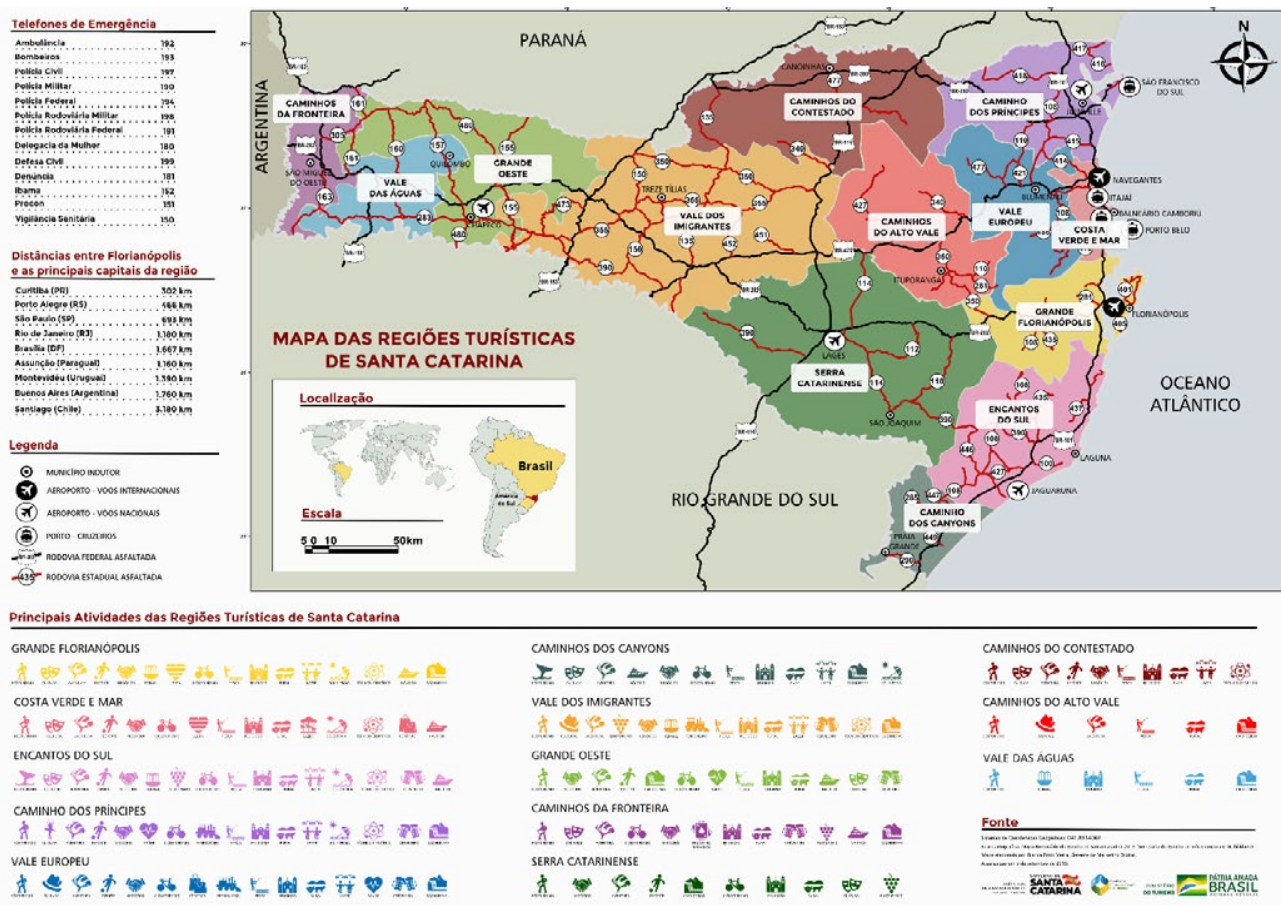

Source: SANTUR, 2019

The "European Valley" region was defined by the State Council of Tourism, following the guidelines of the National Plan for the sector, approved in 2004. This plan has the tourism region as the structuring axis of the national policy through the Tourism Regionalization Program - Roteiros do Brasil (BRASIL, 2004).

It is a management model that associates the notion of territory with that of local productive arrangements as a way of organizing, promoting, qualifying, and diversifying the tourist offer (BORTOLOSSI, 2008). According to Beni (2006, p. 30), this operation consists of "organizing a geographical space into regions for planning, management, promotion and integrated and shared commercialization of the tourist activity".

The promotion of tourist activity in the European Valley exalts the marks and customs of European colonization, emphasizing German and Italian, as well as the natural beauties suitable for ecotourism, adventure tourism, etc. This is expressed by the State Government website:

The cultural heritage of German, Italian, Austrian, Polish, and Portuguese settlers in the great mark of this region of Santa Catarina, located in the Itajaí Valley. Famous for hosting the biggest German festival in the Americas, the Oktoberfest in Blumenau, the European 
Valley has many other attractions: from typical architecture to cuisine, celebrated in style during the October Festivities; ...from ecotourism to rural tourism. Choose your itinerary and have a good trip (SANTA CATARINA, 2014).

More specifically, another site expresses the official historical narrative about the origins of such attractions:

The Itajaí River Valley [which includes the European Valley] was colonized by European immigrants, mainly Germans, who founded Blumenau in 1850. In the last quarter of the 19th century, the Italians settled in the outskirts of the already existing Germanic villages. The descendants of these peoples preserve the customs of their ancestors in cuisine, architecture, folklore, dances, and festivals. The privileged nature of the region provides numerous alternatives for ecotourism and adventure tourism (SANTUR, 2014).

The omission of any reference to the indigenous peoples who inhabited this valley, who rely on their conceptions of nature, values, and ways to meet their needs, is not casual. It only reaffirms the concept that the tourist regionalization of the European Valley has come to enshrine.

That's why Vale Europe is a regional name whose implications go far beyond the planning of tourist activities. It consummates and enshrines the reification of the region, with characteristics that, although imputed and a product of historical and conflicting relationships, are treated as self-evident, naturally given and, therefore, subjectively incorporated as "vocations". This reification takes place as a given representation of the region is accepted and incorporated by social agent's co-builders of the landscape and economic, political, and other agents with the symbolic power to spread their representation of reality, enshrined as a given, natural reality and ahistorical, that is, as a reality in itself.

The occupation of the "European Valley" meant the modeling of the landscape based on the concepts, values, and needs of the colonization populations. This occurred through the delimitation of the lots, according to systems brought from Europe, deforestation, and the "cleaning" and landscaping of the areas close to the houses. Mattedi (2001), when referring to the views of nature that were dominant at different moments in the development process of the Itajaí Valley, emphasizes that, for the settler, local nature represented a threat, an enemy to be subjugated through deforestation and the suppression of certain species, in addition to the elimination of the "bugres", an assumed label of the French used, derogatory, to name the heretics and the sodomites, which had been applied to the American Indians, in the sense of "wild, coarse" (CUNHA, 2009).

Notwithstanding this, the landscapes thus constructed are currently considered evidence of the "tourist vocation" of the region, whose territorial configuration would allow for a balanced way of reconciling non-agricultural rural economic activities with industry and services, attracting urban populations because of their "amenities natural" (VEIGA, 2000). 
Thus, the borders that delimit the "European Valley" result from the naturalization of landscapes and territorial configurations built through social and political relations, linked to specific actors, who are precisely the beneficiaries of the vision that this consecration expresses, that is, the "origin" populations defined in opposition to "Brazilians". The expression "of origin" refers to the way widely used in Santa Catarina to refer to and classify people according to their European ancestry. For example, "this person is of German origin", "that person is of Italian origin", even though they are native Brazilian citizens. The expression "Brazilians" is still used, in some regions, to generically refer to those who would not have European ancestry to invoke. It is an expression that endorses the historical narrative that became hegemonic and affirms the feeling of pioneering in the conquest of the region, strengthening self-esteem and the spirit of unity among those "of origin".

In other words, this regionalization enshrines the transformation of the landscape resulting from violent and traumatic historical processes and is anchored in power relations based on premises that are currently seen as quite questionable.

The exaltation of the "European Valley" for tourism purposes is also a contemporary political phenomenon insofar as it involves rhetoric that obscures the fact that much of the landscape that is a factor of tourist attraction has this shape due to centuries of human activity. of violence and arbitrariness.

From the point of view of socio-environmental ethics, the uncritical consecration of the "European Valley" implies the perpetuation of a way of seeing the landscape and the Itajaí river, typical of colonization, with its modern urban consequences in terms of disasters, and the denial of views and valuations of traditional peoples. These still have their territory affected by the decision to have been chosen during the military dictatorship as a sacrifice zone for the construction of the containment dam known as the North Dam, making it impossible to continue their way of life, traditionally knowing how to live with this entity that in official geography we call "Rio Itajaí Açu".

The Itajaí River basin currently receives three flood containment dams aimed especially at benefiting its most urbanized part, in the municipality of Blumenau. The three dams had significant social and environmental impacts, but the most dramatic impact, also the most denied, was that resulting from the construction of the Norte Dam. It is the largest flood containment dam in Brazil and has drastically and irreversibly changed the daily life of the Xokleng Laklãnõ People (GOULART; FRAGA, 2000), flooding 95\% of their fertile land (PEREIRA et al., 1998). There were no environmental and social impact studies for its construction, nor was there any dialogue with the indigenous people at any point in the decision, design, and construction process. The compensation for the land occupied by the dam's waters was also not paid in full, even though it occupied its best agricultural area and the flat area where there were buildings for ranches, tafas, houses, etc.

The saga of the Xokleng-Laklãnõ People was dramatic for the colonization process. But he had seen some reconstitution at the TI Ibirama, where he restructured his way of life around the river, based on a close relationship, promoting relationships and interactions for generations. The Xokleng-Laklãnõ People - an ancient and ancient culture, with 
a reduced number of survivors as a result of the diseases and massacres practiced - were settled in 1914 in the Ibirama Indigenous Land officially created in 1926. While the colonization process itself represented the first historical loss of its territory, the construction of the North Dam represented its second historic loss.

\section{Final considerations}

The main premises of socio-environmental ethics and an empirical field of application within the domains of regional development from the state of Santa Catarina were presented. It is necessary to discuss the normative assumptions that underlie development perspectives. The cases express regional realities in the state of Santa Catarina which, although they harbor options of questionable value considering the ethical discussion tools available today, are quite naturalized and thus reproduced. The cases refer to: i) the consecration of a pattern of development supported by the reification of sentient beings, which has been characterized as Species Intensive Regions (REIs) and; ii) a tourist regionalization that obliterates and updates a historical process of environmental injustice with indigenous peoples who face the greatest environmental conflict in the state. Each of these cases, in turn, exemplifies one of the dimensions discussed above in the process of constructing socio-environmental ethics. On the one hand, the perspective focuses on the ethical inconsistency of providing animals with merely instrumental treatment. On the other hand, the perspective reveals the disproportionate distribution of environmental burdens and bonuses arising from inequalities inherent in the processes of appropriation of nature, construction of territory, and socio-spatial segregation.

This discussion is relevant because territoriality and urban-industrial-capitalist culture tend to see nature and the non-human from a merely instrumental perspective. And when it moralizes them, it tends to do so by incorporating them into the anthropocentric, white, and colonizing moral universe, condemning everything else to structural objectification or invisibility.

This happens not only in productive systems of monocultures or predatory extractivism, but also with animals. When he places pets on one side and pigs and chickens from industrial farms on the other, he is applying an arbitrary distinction to beings in two universes as opposed to those of humans and things. On the other hand, urban-industrial territoriality produces the structural invisibility of peoples and populations that do not adjust to the implicit normativity of development, as pointed out in the case of the "European Valley".

Socio-environmental ethics implies dealing with the normative arguments underlying the discussions around development, but also with the power relations that appear embodied in the various developmental projects. On the one hand, it is necessary to refine the understanding to discover the best reasons that indicate how one should act about nature and living beings in the different contexts in which they find themselves. On the other hand, it is critical to examine the connections between these defensible arguments and power relations. In other words, it is about building an interface between philosophy and social science and putting it to work to examine disputes in the field of environmental 
values. These disputes take place on the terrain of arguments and the terrain of territory; they are disputes over words as well as a physical, economic and political strength.

The prevalence of the hegemonic logic does not result from the argumentative force of exacerbated anthropocentrism, but from the power relations that mobilize it. Therefore, the necessary normative ethical reflection also requires a look prepared to articulate philosophical arguments with the analysis of social relations.

As a premise for planning, it is important to seek a territorial configuration in which ways of life/territories that are supported by moderate and ecologically intelligent uses of nature, and which are supported by peculiar conceptions of nature, assert themselves and connect, gaining scope, economic, political and territorial. For this, the links of connectivity between them and with urban groups that share such sensitivity, values, and needs are fundamental. These ties, in addition to giving economic scope, can generate political legitimacy and inter-scale solidarity, beyond the local.

These ties with cities are crucial to prevent decisions that ignore the rights of these peoples under the logic that are only justified on other territorial scales.

Ecological degradation is always associated with the instrumental reduction of nature and beings. That is why overcoming instrumental reduction is away, if not sufficient, but necessary to respond to ecological degradation in the situation in which we find ourselves. Allowing these other valuations to establish their moral limits to the use of landscapes and living beings is the most immediate way to take socio-environmental ethical criteria seriously in development planning. This is why "ecological consciousness" needs a territorial reading, which is precisely what is ignored by exclusively technical discourses and by ecological common sense.

\section{Acknowledgments}

To the National Council for Scientific and Technological Development (CNPq), the State of Santa Catarina Research and Innovation Support Foundation (FAPESC), and the Santa Catarina Association of Educational Foundations (ACAFE).

\section{Bibliographic References}

ACSELRAD, H. O que é justiça ambiental. RJ: Garamond. 2008.

ANTONSICH, M. Rethinking territory. Progress in Human Geography, v. 35, n.3, p. 422-425, 2011.

BAUMAN, Z. Comunidade. RJ: Zahar, 2003.

BECK, U. Risk society. Londres: SAGE, 1992.

BERGER, P. L. Perspectivas sociologicas. Petropolis: Vozes, 2000. 202p. (Antropologia, 1). 
BOURDIEU, P. O poder simbólico. RJ: Bertrand, 1989.

BREKKE, T. Entrepreneurship and path dependency in regional development. Entrepreneurship \& Regional Development, v.27, n.3,4, mar, p. 202-218, 2015.

CUNHA, M. C. da. Política indigenista no século XIX. In: CUNHA, M. C. (Org.) História dos índios no Brasil. SP: Cia Letras; SMCultura/SP; FAPESP, 2009. p. 133-154.

DANA, L et al. Entrepreneurship, tourism, and regional development. Entrepreneurship $\mathbb{E}$ Rgional Development, v. 26, n.3-4, mar, p. 357-374, 2014.

DANOWSKI, D.; VIVEIROS de CASTRO, E. Há um mundo por vir? Florianópolis, Cultura e Barbárie e Instituto Socioambiental, 2014, 176p.

DE LA CADENA, M. Indigenous Cosmopolitics In The Andes: Conceptual Reflections beyond "Politics". Cultural Anthropology, v.25, n. 2, p. 334-370, 2010.

ELLIOT, R. (2004). La ética ambiental. In: Singer, P. (Ed.). Compendio de ética. Madrid: Alianza Editorial, p. 391-404.

ESCOBAR, A. Political ecology of globality and diference. Gestión y Ambiente, v. 9, n. 3, 2006, p. 29-44.

FIESC. FEDERAÇÃO DAS INDÚSTRIAS DO ESTADO DE SANTA CATARINA. Santa Catarina em dados 2015. Florianópolis: FIESC, v. 25, 2015. Disponível em: < http://fiesc.com. br/sites/default/files/medias/sc_em_dados_site_correto.pdf $>$. Acesso em: 19 Out.2017.

FLORIT, L. Ética ambiental ocidental e os direitos da natureza. Revista Pensamiento Actual, v. 17, p. 121-136, 2017.

FLORIT, L. et al.Índios do "Vale Europeu. Novos Cadernos NAEA v. 19, n. 2, p. 21-41, 2016.

FLORIT, L. e SBARDELATI, C. Intensive Speciesism Regions in Brazil. In: Talia R.; Dora M. (Org.). (2016) Impact of Meat Consumption on Health and Environmental Sustainability. Hershey, Pennsylvania: IGI Global, 2016. p. 277-294.

FLORIT, L.; GRAVA, D. S. Ética ambiental e desenvolvimento territorial sustentável. Ambiente \& Sociedade, v. 19, p. 23-42, 2016.

FLORIT, L. Conflitos ambientais, desenvolvimento no território e conflitos de valoração. Desenvolvimento e Meio Ambiente, v. 36, p. 255-271, 2016.

FLORIT, L. A reinvenção social do natural. Blumenau: Edifurb, 2004, 192p.

FLORIT, L. et al. Da ética ambiental normativa às relações de poder. In: 18º Congresso de Sociologia, 2017, Brasília. Anais ..., Brasília, 2017.

FLORIT, L. et al. Os desafios da ética socioambiental. In: FLORIT, L. F; SAMPAIO, C. A.; 
PHILIPPI Jr, A. (Eds) Ética Socioambiental. Barueri: Manole, 2019.

FRIEDMAN, V. J.; DESIVILYA, H. Integrating social entrepreneurship and conflict engagement for regional development in divided societies. Entrepreneurship $\&$ Regional Development, v. 22, n. 6, p. 495-514, 2010.

GENNAIOLI, N. et al. Human capital in regional development. Quarterly Journal of Economics, v.128, n.1, p. 105-160, 2013.

GRAVA, D. S. Vocações regionais, território e justiça socioecológica. In: FLORIT, L. F.; SAMPAIO, C. A. C.; PHILIPPI Jr., A. (Org.). Ética Socioambiental. Barueri: Manole, 2019. p. 231260.

GUDYNAS, E. Ecología, economía y ética del desarrollo sostenible. Quito: Montevideo: Ediciones Abya-Yala, 2003.

GIDDENS, A. Consecuencias de la modernidad. Madrid, Alianza, 1993.

INGOLD, T. Trazendo as coisas de volta à vida. Horizontes antropológicos, v. 18, n. 37, p. 25 44, 2012.

JACOBI, P. R. et al. Hibridismo, conhecimento e ética socioambiental. IN: FLORIT, L. F; SAMPAIO, C. A. C.; PHILIPPI JR., A. Ética socioambiental. Barueri: Manole, 2019.

LEGARDA, A. A.; Pardo, B. M. Justicia ambiental: el estado de la cuestión. Revista Internacional de Sociologia (RIS), v. 69, n. 3, 627-648, 2011.

KUHNEN, T. A. É possível ir além dos animais sencientes na definição dos limites da comunidade moral? In: ROUANET, L. P. e CARVALHO, M. C. M. de (Orgs). Ética e direitos dos animais. Florianópolis, EdUFSC, 2016. p 181-220.

MARZOCHI, S. F; FLORIT, L. F. Ética ambiental no Brasil. Contemporânea, v. 8, p. 343-356, 2018.

MÜLLER, M. O. et al. Energy autarky. Energy Policy, v. 39, n. 10, p. 5800-5810, 2011.

PEDRO, A. P. Ética, moral, axiologia e valores. Revista Kriterion, Belo Horizonte, nº 130, dez., 2014, p. 483-498.

PORCHER, J. Zootecnia. Laboreal, v. 8, n. 1, 2012.

RACHELS, J.; RACHELS, S. Os elementos da filosofia da moral. PA: AMGH, 2013. 208 p.

SANTUR - AGÊNCIA DE DESENVOLVIMENTO DO TURISMO DE SANTA CATARINA. Mapa do turismo 2019 - PT - BR. Disponível em: < http://santur.sc.gov.br/index. php? option $=$ com_docman $\&$ view $=$ list $\&$ slug $=$ mapa-do-turismo $\&$ Itemid $=401$ \&layout $=$ tab le $>$. Acesso em: $27 /$ fevereiro/2021. 
SANTA CATARINA. Lei no 12.854, de 22 de dezembro de 2003: Institui o código estadual de proteção aos animais. Governo do Estado de Santa Catarina, 22/12/2003. Disponível em: <http://www.icmbio.gov.br/cepsul/images/stories/legislacao/Lei/2003/lei_sc_12854_2003_instituicodigoestadualprotecaoanimais_sc.pdf $>$. Acesso em: 25/Jul/2018.

SANTOS, R. dos S.; PIROLI, E. L. Planejamento ambiental e a perspectiva escalar. Geosul, v.35, n. 75, p. 350-375, 2020.

SILVA, R.; FERREI.RA-L., A. A regional development Index for Portugal. Social Indicators Research, v.118, n. 3, p. 1055-1085, 2014.

VIVEIROS DE CASTRO, E. The relative native. HAU: Journal of Ethnographic Theory, v.3, n. 3, p. 473-502, 2013. 


\section{Luciano Felix Florit}

$\square$ lucianoflorit@gmail.com

ORCiD: https://orcid.org/0000-0001-5437-8234
Submitted on: 01/06/2020

Accepted on: 21/07/2021

2021;24e:01222

\section{Carlos Alberto Cioce Sampaio}

$\varangle$ carlos.cioce@gmail.com

ORCiD: https://orcid.org/0000-0002-0664-026

How to cite: FLORIT, L. F; SAMPAIO, C. A. C. Social-environmental ethics as an approach to regional development. Ambiente $\mathbb{\&}$ Sociedade. São Paulo, v. 24, p. 1-20, 2021. 


\title{
Ética Socioambiental como abordagem do Desenvolvimento Regional
}

\author{
Luciano Félix Florit \\ Carlos Alberto Cioce Sampaio
}

São Paulo. Vol. 24, 2021

Artigo Original
Resumo: As concepções de desenvolvimento predominantes não conseguem correlacionar de modo consistente a questão social e a temática ecológica com um projeto de país de longo prazo. A reflexão ético-política em torno dos padrões de desenvolvimento é, portanto, uma reflexão crucial. Objetiva-se dialogar a respeito do desenvolvimento regional confrontando-o a partir da explicitação de categorias da ética socioambiental. Trata-se de uma pesquisa exploratória que se apoia empiricamente na análise de documentos de dois casos do processo de regionalização no estado de Santa Catarina (Brasil). Conclui-se que reconhecer limites morais legítimos ao uso das paisagens e dos seres vivos seria um momento importante do planejamento do desenvolvimento, o que requer uma leitura territorial. Isto, é ignorado pelos discursos exclusivamente técnicos e senso comum ecológico.

Palavras-chave: Desenvolvimento Regional; Ética socioambiental; Seres vivos humanos e não humanos; Santa Catarina; Território.

Como citar: FLORIT, L. F; SAMPAIO, C. A. C. Ética Socioambiental como abordagem do Desenvolvimento regional. Ambiente $\&$ Sociedade. São Paulo, v. 24, p. 1-20, 2021.

DOI: http://dx.doi.org/10.1590/1809-4422asoc20200122r2vu2021L5AO 


\title{
Ética socioambiental como enfoque del desarrollo regional
}

\author{
Luciano Félix Florit \\ Carlos Alberto Cioce Sampaio
}

São Paulo. Vol. 24, 2021

Resumen: Las concepciones de desarrollo más comunes no logran cor-

Artículo original relacionar consistentemente las cuestiones sociales y la cuestión ecológica con un proyecto de país a largo plazo. La reflexión ético-política en torno a los patrones de desarrollo es, por tanto, una reflexión crucial. El objetivo es reflexionar sobre desarrollo regional, a partir de categorías de ética socioambiental. Se trata de una investigación exploratoria que se basa empíricamente en el análisis documental de dos casos de regionalización del estado de Santa Catarina (Brasil). Se concluye que reconocer límites morales legítimos al uso de paisajes y seres vivos es un momento importante en la planificación del desarrollo, lo que requiere una lectura territorial. Esto es ignorado por los discursos exclusivamente técnicos y las concepciones ecológicas más comunes.

Palabras-clave: Desarrollo regional; Ética socioambiental; Seres vivos humanos y no humanos; Santa Catarina; Territorio.

Como citar: FLORIT, L. F.; SAMPAIO, C. A. C. Ética socioambiental como enfoque del desarrollo regional. Ambiente $\mathbb{\&}$ Sociedade. São Paulo, v. 24, p. 1-20, 2021.

DOI: http://dx.doi.org/10.1590/1809-4422asoc20200122r2vu2021L5AO 